\title{
Lifestyle Sports in East Asia
}

\section{Clifton Evers \& Adam Doering}

Lifestyle sports (e.g. surfing, snowboarding, BASE jumping, skateboarding, rock climbing, freerunning, BMX) are not the preserve of occidental cultures, even though late capitalist Western nations dominate them commercially and ideologically. Non-occidental cultures - such as those in Asia, Latin America, Africa - also influence lifestyle sport institutions, commodities, values, and practices. Arguably, this influence is expanding and is accelerating as the populations of non-occidental cultures champion their interests and perspectives when it comes to lifestyle sports.

The cultural politics of "lifestyle sports" (Wheaton, 2013) involves identity, space, commodification, environment, colonialism, labour, and more. While the cultural politics of lifestyle sports may seem trivial to some, personally we agree with Stuart Hall's (1981) argument that

Popular culture is one of the sites where this struggle for and against a culture of the powerful is engaged: it is the stake to be won or lost in that struggle. It is the arena of consent and resistance. (239)

Lifestyle sports are also referred to as "action sports" (Thorpe, 2014), "extreme sports” (Rinehart \& Sydnor, 2003), "adventure sports” (Breivik, 2010), as well as other such terminology. Here we use the term "lifestyle sport" because participants in this region discuss their involvement and enthusiasm through a "lifestyle" narrative. That said, Ding (this issue) and Evers (2017) note how the mainstream and enthusiast media in China use the term "Jixian yundong" (X-Sports). Consistent features of these "sports" - whether they should be called "sports" is debated by enthusiasts, hence the inverted commas - include a tension between competition and a non-competitive ethos, institutionalization and anti-institutionalization, as well as commodification and anti-commodification. Lifestyle sports tend to be 
informally organized, be less rule-governed (although they have their own informal cultural rules), and most enthusiasts prioritize individual recreational participation. The sports have cultures that organise around the respective enthusiasms and associated skill-based challenges, with all the subcultural capital this entails (Fuller, 2009; Thornton, 1995).

This special issue make the modest proposal for the starting of a targeted discourse among those interested in the cultural politics of lifestyle sports in the region of East Asia, an area with its own unique intractions and concomitant interests, needs, desires, and perspectives. In specific regard to this region, we argue it is worth asking: What are the stories being narrated and what forms do they take? How are complex social, political, cultural, and economic relations of this region being negotiated through lifestyle sports? Following Chen (2010), we recognize how intra-regional exchange is often most influential. Commonly, including studies of lifestyle sports, scholarship focuses on the influence of the West and/or what most matters to those in the West. A number of Indigenous scholars are providing examples of how to proceed while privileging their own epistemologies and ontologies (Gilio-Whitaker, 2017; Ingersoll, 2016; McGloin, 2017).

Our modest rallying cry proceeds while fully aware that it is not settled how to define "Asia" (Horton, 2011). One way to understand such is as a continental mass (although then it should be called Eurasia given the continent stretches all the way to Europe) (Ibid). Asia has also been explained as a discursive construct that contributes to a strategic separation of an "us" (the West) from "them" (the Other) (Said, 2003).

But what of the term "East Asia"? It has been argued to have emerged from a regionalism that began in the late 1800 s, a product of intellectuals and governments arguing for the representing of the convivial and conflictual interrelationships (economic, cultural, social) between a number of nation-states as sufficient evidence of a definable region (Hitochi, 2008). This is an "imagined 
community" (Anderson, 1983). There is no settled identity of "East Asia" due to shifting interests and alliances (Hitochi, 2008). Cultural and socio-economic diversity is immense (Yul, 2009). As per the idea of an "Asia," debates as to who can or should be members of the region, what constitutes the area, and its institutionalisation continue (Ibid). For now, we understand East Asia to signify a region that includes member states Japan, China, Hong Kong, Macau, Taiwan, Mongolia, North Korea, and South Korea (Prescott, 2015).

The experience of seeking out and collating submissions for this special issue has revealed to us that a coordinated and collaborative strategy needs to be developed through more inclusive research practices and better resourcing so that Indigenous scholars of East Asia get to lead and advance this discourse. Three of the authors and editors of this special issue are white male English-as-first-language academics originally from the West. As such, they (and the editors) remain bound to what Edward Said refers to as a discursive process of Orientalism. While that is the case at the moment, we are hoping the modest proposal here helps in some small way to co-create spaces for, galvanise support for, and help amplify Indigenous scholarship about lifestyle sport in East Asia. It is worth noting here that what we are not doing is advocating simply trying to achieve a wider range of perspectives that would have us include who Martin Nakata (2007) refers to Indigenous 'knowers' and the experiences that inform them. Rather, we are listening to Nakata's guidance that the goal should be to seek out better understanding and more informed standpoints formed through the "critical analysis of accepted positions and arguments" that this "knowing and experience can bring about" (214). Our hope is that future discourse about lifestyle sport in East Asia gets to proceed by entering a referential space that undermines any reproduction of Western hegemony and "imperialist desire" that some of the authors here and editors, whether we like it or not, can be vessels for (Chen, 2010, p. 41).

Most studies of lifestyle sports to-date focus on and proceed from late capitalist Western contexts, such as the United States, Aotearoa New Zealand, Europe, and 
Australia. However, a growing body of literature critically analyses lifestyle sports in Africa, Latin America, South-East Asia, and the Asia-Pacific is challenging that hegemony. When it comes to East Asia, many lifestyle sports communities are still relatively new so critical scholarship (particularly Indigenous) is still rare. Japan is an exception because some lifestyle sports have a longer history. That said, critical lifestyle sport scholarship isn't exactly common. Perhaps the recent inclusion of surfing, skateboarding, and sport climbing in the Tokyo Olympics 2020 will lead to increased interest, participation, and investment in lifestyle sports (Wheaton \& Thorpe, 2018)..$^{1}$ Consequently, scholarship may be made more possible as governments, funding bodies, and sporting organisations recognize the value of scholarship about how the respective communities participation is connected to health, wellbeing, environmental politics, labour, identity, urban planning, and much more. However, evidence to-date about how much of an increase and concomitant influence Olympics inclusion will have on lifestyle sport interest continues to proceed as a best guess scenario. Holly Thorpe and Belinda Wheaton (2016) have conducted a global survey for the International Olympic Committee about effects of inclusion of lifestyle sports in the Olympics. They have found that interest is likely to increase.

While lifestyle sports may not have particularly long histories in all of East Asia regional Indigenous interpretations and place-specific trajectories have emerged and will continue to do so. For example, in China interest in lifestyle sport participation has accelerated since being propelled by government investment to achieve Olympic success. Prior to this growth had been slower as it had been organic, and lacked governmental legitimation and structural investment e.g. in facilities and training (Evers, 2017; Sedo 2010; Xiaochen, 2017). China has a long history of sport being conspicuously connected to national identity, nationalist pride, "harmonization," soft power, and international standing (Xu, 2006). That said, there is resistance as lifestyle sports participants worry about a 'loss' of the smaller grassroots culture they have built to-date (Evers, 2017; Six Stair, 2019). In 
many parts of the world, the strength of a 'counter-culture' discourse has resulted in heated debate in respective lifestyle sport subcultures about the politics of institutionalisation and popularisation that occurs because of inclusion in the Olympics (Honea, 2014; Thorpe \& Wheaton, 2011; Wheaton \& Thorpe, 2018).

What about now? What studies exist about lifestyle sports in East Asia? We are not aware of any studies of lifestyle sports in Mongolia and the Koreas, with the exception of Sanders Holgens who is studying skateboarding in South Korea (this issue). There is some scholarship analysing the implications of surf tourism in Taiwan (Cheng \& Tsaur, 2012), as well as a psychological discourse about enthusiasts'- surfing, skateboarding, extreme blade, and BMX - experiences of 'flow' during participation (Cheng \& Lu, 2015).

A small body of literature exists about the cultural politics of lifestyle sports in regards to China. Based on predominantly Western media reports, Holly Thorpe $(2008,2014)$ provides several overviews of "action sports" in China. Clifton Evers (2017) conducted ethnographic work in China to provide a mapping of contemporary surfing in relation to Chinese social conditions, identity politics, tourism, and economics. Following the 2008 Beijing Olympics, Mark Dyreson (2012) used BMX as a case study to interrogate how inclusion of this sport perpetuated attempts for global ideological superiority to be achieved through the Olympics. During a brief visit to China, Adele Pavlidis and Wendy O’Brien (2017) connected with a very new roller derby league, primarily made up of Western expatriates. They argue that interaction between the ethos of roller derby, the expatriates, and local Chinese enthusiasts has the potential to function as a site of feminist politics in the country. A number of foreign skateboarding scholars that live or have lived in China and explored the politics of place, regulation, institutionalisation, and identity manifested through skateboarding (O'Connor, 2016, 2018; Sedo, 2010). ${ }^{2}$ Paul O'Connor (2018) who resides in Hong Kong develops his previous considerations of the politics of place to take into account the role of "network capital" in how lifestyle sports function in East Asia. 
O'Connor provides a case study of how Indigenous skaters and their personal relationships are operationalised by the global industry to achieve (and at the least, signify) international relevance, reach, commercialization, and exoticism. An effect is that despite Hong Kong not being a 'skate friendly' city it is constructed as a key node in the international skating industry and community. What all these studies of lifestyle sports in China have in common is that they are done by non-Indigenous scholars so there are limitations to what they can teach us, and the accuracy of interpretation and findings still require Indigenous evaluation.

Within the context of Japan, academic scholarship is nationally rather than internationally focused, written in Japanese language, and published within difficult to access in-house journals designed for domestic audiences (Yamashita, 2015). For these reasons, amongst others, there is lack of knowledge and contribution to lifestyle sports literature both within Japan and beyond its national borders. There are, however, a few sporadic publications offering empirically rich insights concerning a range of lifestyle sports in Japan. Through long-term ethnographic work with skateboarders in urban spaces, Tanaka $(2004 ; 2007)$ examines how skateboarders collectivise to achieve a sense of agency in public spaces in the face of rigid social stratification. Helpful complimentary work is provided by Dwayne Dixon $(2011,2016)$ who through his studies in Tokyo argues that skaters not only document their skateboarding lives but also how it relates to their increasingly transnational identities, job insecurity, and educational concerns. Wolfram Manzenreiter's (2013) brings gender into consideration in his work on lifestyle sports in Japan. He uses rock climbing to examine if alternative sports offer an opportunity to establish alternative modes of masculinity. Manzenreiter finds that despite shifting discourses that celebrate a shift to gender relations through lifestyle sport, for men in Japan rock climbing continues to be an arena of "hypermasculinity." Studies on the role, importance and function of surf culture and destinations in Japan has also started to garner attention. The English literature on surfing in Japan tends to discuss the historical trajectory, origins, and politics of 
surfing in Japan (Laderman, 2016; Moore, 2010), with others emphasising the value of the Japan as a niche surf market within the global surf cultural industry (Warshaw, 2010; Westwick \& Neushul, 2013). Recent studies have emerged concerning the current issues and possibilities of surf tourism as a tool for rural revitalisation (Doering, 2018). Japanese language scholarship tends to focus on either the sport's origins or current potential to created economic value through tourism (Kobayashi, 2013; Kobayashi, Nishida, \& Matsumoto, 2011, 2012; Konagaya, 2005, 2009). An exception is the work of ground-breaking work of Eri Mizuno, (2002, 2007, 2015, 2018). Mizuno's research draws our attention to the significant barriers and limitations of female participation in lifestyle sports, but also demonstrates the ways female surfers find agency within and against a highly patriarchal mode of local surf break governance.

This special issue contributes three more articles (plus this summary of the regional subfield) to a discourse about lifestyle sport in East Asia that proceed from empirical ethnographic evidence. Sander Holsgens breaks new ground by taking us into South Korea, specifically Ttueksom Hangang Park located in central-east Seoul. The article is a phenomenological analysis that explains how enthusiasts orientate to clearly defined circumstances e.g. specific architecture. Holsgens finds that the enthusiasts do not develop some fluid bodily technique adaptable to any circumstance (as is often argued in regards to lifestyle sports) but rather cultivate distinct skillsets achieved through repetition in a culturally and materially bounded setting. Yiyin Ding provides a rare Indigenous account of the urban BMX scene in China, and in so doing provide crucial context for understanding experiences of lifestyle sports more generally in China. Ding delivers a first-hand account of how subcultural politics (e.g. tensions between mainstream acceptance and subcultural respect) and filial piety prove to be the two important matters of concern for Chinese enthusiasts trying to build a career through BMX. Adam Doering and Clifton Evers shift attention to Japan via an analysis of the gendering of a particular surf scene that proceeds through instantiations of a domestic patriarchal 
gender order. However, it is an order that is being reinforced through transnational relationships with Indigenous surfing masculinities in Hawai'i. Their findings challenge scholarship that would simply have transnational cultural flows and mobilities displacing local and national ways of life (see Anderson, 2014).

Again, we hope this modest special issue can begin to in some small way galvanise a cohesive discourse about lifestyle sports in East Asia. The goal is to not only support a politics of voice and pathbuilding but an ethics of listening, a conversation that hopefully can result in better understanding and more informed standpoints (Nakata, 2007; O’Donnell et al., 2009). Efforts - championed particularly by feminist scholars, Indigenous scholars, and those arguing for decolonisation - have been made to move away from particular hegemonic foci (for example see Ingersoll, 2016; Gilio-Whitaker, 2017; Walker, 2011). The modest move here is inspired - both politically and personally - to be allies for such in this particular region.

\section{Reference list}

Anderson, B. (1983). Imagined Communities: Reflections on the Origin and Spread of Nationalism. London: Verso.

Bickford, S. (1996). The Dissonance of Democracy: Listening, Conflict, and Citizenship, Ithaca, NY: Cornell University Press.

Breivik, G. (2010). Trends in Adventure Sports in a Post-modern Society. Sport in Society, 13(2), 260-273.

Chen, K-H. (2010). Asia as Method: Toward Deimperialization. Durham: Duke University Press.

Cheng, T-M. \& Lu, C-C. (2015.) The Causal Relationships among Recreational Involvement, Flow Experience, and Well-being for Surfing Activities. Asia Pacific Journal of Tourism Research, 20(1), 1486-1504 
Cheng, T-M. \& Tsaur, S-H. (2012). The Relationship Between Serious Leisure Characteristics and Recreation Involvement: A Case study of Taiwan's Surfing Activities. Leisure Studies, 31(1), 53-68.

Dixon, D. (2011). Getting the Make: Japanese Skateboarder Videography and the Entranced Ethnographic Lens. Postmodern Culture, 22(1). Retrieved from http://www.pomoculture.org/2013/05/18/3194/

Dixon, D. (2016). Posing LA, performing Tokyo. Photography and Race in Skateboarding's Global Imaginary. In K. J. Lombard (Ed.), Skateboarding: Subcultures, Sites and Shifts (pp. 74-80). London: Routledge.

Doering, A. (2018). Mobilising Stoke: A Genealogy of Surf Tourism Development in Miyazaki, Japan. Tourism Planning \& Development, 15(1), 68-81.

Dyreson, M. (2012). World harmony or an Athletic 'Clash of Civilizations'? The Beijing Olympic Spectacle, BMX Bicycles and the American Contours of Globalisation. The International Journal of the History of Sport, 29(9), 1231-1242.

Evers, C. (2017). Surfing and Contemporary China. In D. Z. Hough-Snee \& A. S. Eastman (Eds.), The Critical Surf Studies Reader (pp. 386-402). Durham: Duke University Press.

Fuller, G. (2009). The Challenges of Enthusiasm. M/C Journal, 12(2). Retrieved from http://journal.media-culture.org.au/index.php/mcjournal/article/view/161 Gilio-Whitaker, D. (2017). Appropriating Surfing and the Politics of Indigenous Authenticity. In D. Z. Hough-Snee \& A. S. Eastman (Eds.), The Critical Surf Studies Reader (pp. 214-232). Durham: Duke University Press.

Hall, S. (1981). Notes on Deconstructing the Popular. In R. Samuel (Ed.), People's History and Socialist Theory (pp. 227-240). London: Routledge and Kegan Paul.

Hebdige, D. (1988). Subculture: The Meaning of Style. London: Routledge. 
Hitochi, H. (2008). Japanese Concept of East Asia - Its History and Now. East Asia Regional Concept and Chinese View of Japan and Korea, 34th SGRA FORUM, 8th Asian Future Forum of Japan and Korea, February 21.

Honea, J. C. (2013). Beyond the Alternative vs. Mainstream Dichotomy: Olympic BMX and the Future of Action Sports. Journal of Popular Culture, 1253-1275.

Horton, P. (2011). Sport in Asia: Globalization, Glocalization, Asianization. In P. Pachura (Ed.), New Knowledge of Globalization (pp. 119-146). Rijeka: Intech Open. Ingersoll, K. (2016). W aves of Knowing: A Seascape Epistemology. Durham: Duke University Press.

Kobayashi, K. (2013). Kugenumakaigan de no sāfin no hasshō zenshi [The early history of surfing along the Kugenuma coast]. Bunkyo University Journal of the Faculty of International Studies, 23(2), 1-11.

Kobayashi, K., Nishida, R., \& Matsumoto, H. (2011). Chigasaki-shi no sāfin kanren sangyō no hasshō to suii [The origin and history of industries related to surfing in Chigasaki City]. Shōnan Forum, 16, 107-118.

Kobayashi, K., Nishida, R., \& Matsumoto, H. (2012). Nïjima ni okeru sāfin ni yoru kankō yūchi no ikisatsu [The historical details of attracting tourists to Niijima island with surfing]. Bunkyo University Journal of the Faculty of International Studies, 22(2), 13- 24.

Konagaya, Y. (2005). Nihon ni okeru safin no juyo katei [The diffusion process of modern surfing in Japan]. Rikkyo University School of Tourism Bulletin, 7, 1-16.

Konagaya, Y. (2009). Safuin bunka no keisei to kukan to iu media [Development of surfing culture and media space]. In K. Kanda (Ed.), Rejya no kukan: shosō to apurōchi (pp. 59-67). Kyoto, Japan: Nakanishiya.

Laderman, S. (2014). Empire in Waves: A Political History of Surfing. Berkeley: University of California Press. 
Lawler, K. (2011). The American Surfer: Radical Culture and Capitalism. New York: Routledge.

Manzenreiter, W. (2013). No pain, no gain: embodied masculinities and lifestyle sport in Japan. Contemporary Japan, 25(2), 215-236.

McGloin, C. (2017). Indigenous Surfing: Pedagogy, Pleasure, and Decolonial Practice. In S. Z. Hough-Snee \& A. S. Eastman (Eds.), The Critical Surf Studies Reader (pp. 196-213). Durham: Duke University Press.

Mizuno, E. (2002). Supōtsu to kaibunka ni tsuite no ichikōsatsu: X sāfu shoppu ni mirareru dansei bun [A study on sports and subculture: 'Male culture' at surf shop X]. Kyoto Journal of Sociology, 10, 35-60.

Mizuno, E. (2007). Supōtsu to kanyō-sei: sāfin kyōdōtai ni okeru jendā to rōkarizumu [Sports and tolerance: gender and localism in surfing communities]. In A. Sadamichi (Ed.), Tagenteki sekai ni okeru kanyō to kökyö-sei: Higashiajia no shiten kara (pp. 198-214). Kyoto: Koyo Shobō.

Mizuno, E. (2015). Nihon ni okeru sāfin o suru josei no 50-nen (1): 1990-nen ikō no sāfin bunka to jendā kōhei [50 years of women surfing in Japan (1): Surfing culture and gender equity since the 1990's]. University of Marketing and Distribution Sciences Journal of Human and Society: Nature Edition, 28(1), 53-76.

Mizuno, E. (2018). Multiple marginalization?: representation and experience of bodyboarding in Japan. Surfing, Sex, Genders and Sexualities (pp. 89-108). New York: Routledge.

Moore, M. S. (2010). Sweetness and Blood: How Surfing Spread from Hawaii and California to the Rest of the World, with Some Unexpected Results. New York: Rodale.

Nakata, M. (2007). Disciplining the Savages, Savaging the Disciplines. Canberra: Aboriginal Studies Press. 
O'Connor, P. (2016). Skateboarding, Helmets, and Control: Observations from

Skateboard Media and a Hong Kong Skatepark. Journal of Sport and Social Issues, 40(6), 477-498.

O’Connor, P. (2018). Handrails, Steps and Curbs: Sacred Places and Secular Pilgrimage in Skateboarding. Sport in Society, 21(11), 1651-1668.

O’Connor, P. (2018). Hong Kong Skateboarding and Network Capital. Journal of Sport and Social Issues, 42(6), 419-436.

O’Donnell, P., Lloyd, J., Dreher, T. (2009). Listening, Pathbuilding and Continuations: A Research Agenda for the Analysis of Listening. Continuum: Journal of Media \& Cultural Studies, 23(4), 423-439.

Pavlidis, A. \& O’Brien W. (2017). Sport and Feminism in China: On the Possibilities of Conceiving Roller Derby as a Feminist Intervention. Journal of Sociology, 53(3), 704-719.

Prescott, A. (2015). East Asia in the World: An Introduction. London: Routledge. Rinehart, R. E. \& Sydnor, S. (Eds.). (2003). To the Extreme: Alternative Sports, Inside and Out. Albany: State University of New York Press.

Said, E. (2003). Orientalism. London: Penguin Books.

Sedo, T. (2010). Dead-stock Boards, Blown-out Spots, and the Olympic Games: Global Twists and Local Turns in the Formation of China's Skateboarding Community. In: P. Rethmann, I. Szeman, \& W. Coleman (Eds.), Cultural Autonomy: Frictions and Connections (pp.257-282). Vancouver, British Columbia: University of British Columbia Press.

Six Stair (2019). Loveletters to Skateboarding: China (season 10). Available at https: / $/$ www.youtube.com/watch?time continue $=1193 \& v=$ ifhAOpXH1PM

Tanaka, K. (2004). "Wakamono hiroba" setchi katsudo ni miru toshi kai bunka no aratana doko: "Tsuchiura eki nishiguchi hiroba" setchi o motomeru jakunenso no 
shojissen kara [New trends in urban subcultures in acquiring an "open space" for youth groups]. Nenpō shakai-gaku ronshü [Annual Review of Sociology], 17, 120-131.

Tanaka, K. (2007). Wakamono kai bunka to shakaiteki haijo [Youth Subculture and Social Exclusion]. Japan Journal of Sport Sociology, 15, 71-85.

Thornton, S. (1995). Club Cultures: Music, Media and Subcultural Capital. Cambridge: Polity Press.

Thorpe, H. (2008). Extreme sports in China. In F. Hong with D. Mackay, \& K. Christensen (Eds.), China Gold: China's Quest for Global Power and Olympic Glory. Great Barrington, MA: Berkshire.

Thorpe, H. \& Olive, R. (Eds.). (2016). Women in Action Sport Cultures: Identity, Politics and Experience. Basingstoke: Palgrave Macmillan.

Thorpe, H. \& Wheaton, B. (2011). 'Generation X Games', Action Sports and the Olympic Movement: understanding the Cultural Politics of Incorporation. Sociology, 45(5), 830-847.

Thorpe, H. \& Wheaton. B. (2016). Youth Perceptions of the Olympic Games: Attitudes Toward Action Sports at the YOG and Olympic Games. Report for the International Olympic Committee. Retrieved from https://library.olympic.org/Default/doc/SYRACUSE/165853/youthperceptions-of-the-olympic-games-attitudes-towards-action-sports-at-the-yog-andolympic-games-? $\mathrm{lg}=\mathrm{en}-\mathrm{GB}$

Walker, I. H. (2011). Waves of Resistance: Surfing and History in Twentieth-Century Hawaii. Honolulu: University of Hawai'i Press.

Westwick, P., \& Neushul, P. (2013). The world in the curl: An unconventional bistory of surfing. New York: Crown.

Wheaton, B. (2013). The Cultural Politics of Lifestyle Sports. London: Routledge. 
Wheaton, B. \& Thorpe, H. (2018). Action Sports, the Olympic Games, and the Opportunities and Challenges for Gender Equity: The Cases of Surfing and Skateboarding. Journal of Sport and Social Issues, 42(5), 315-342.

Xiaochen, S. (2017, August 8). Search for 'Extreme' Olympic Athletes Going Global. China Daily. Retrieved from http://www.chinadaily.com.cn/kindle/201708/08/content_30372332.htm

Xu, X. (2006). Modernizing China in the Olympic Spotlight: China's National Identity and the 2008 Beijing Olympiad. The Sociological Review, 54(2), 90-107.

Yamashita, S. (2015). East Asian Anthropology: A Japanese Perspective. American Anthropologist, 117(2), 376-377.

Yul, S. (2008). Korean Concept of East Asia - Korean Regionalism. East Asia Regional Concept and Chinese View of Japan and Korea, 34th SGRA FORUM, 8th Asian Future Forum of Japan and Korea, February 21.

\footnotetext{
${ }^{1}$ Snowboarding became part of the Olympics in 1998.

${ }^{2}$ We identified via an online database known as CAB Direct a number of studies about " $X$-sports" - the most oft-used term in Chinese scholarship for these sports - however there has been no way to verify the scholarship. A Chinese scholar was employed to locate and verify scholarship. However, they too have been unable to do so with article weblinks being dead and respective journal articles unable to be located in full. As such, we proceed here without using the material from this database until research can be verified.
} 